\title{
ARGUMENTATIVE HYPOCRISY AND CONSTITUENT DEBATES: THE ITALIAN CASE
}

\author{
HIPOCRISIA ARGUMENTATIVA E DEBATES CONSTITUINTES: O \\ CASO ITALIANO
}

\author{
Giovanni Damele* \\ giovanni.damele@fcsh.unl.pt
}

\begin{abstract}
Jon Elster suggested that even speakers who are not moved "by a concern for the common good", but whose concerns are "purely self-interested", may be still forced or induced "to substitute the language of impartial argument for the language of self-interest". This substitution would be the fruit of the civilizing force of hypocrisy. This argumentative hypocrisy is a key concept for understanding a process of negotiation through persuasive strategies typical in constitutional debates. Particularly, Elster believes that "the most important requirement" of a bargaining theory should be "that we are able to specify what will happen during a temporary breakdown of cooperation". The constituents can get out of an impasse caused by a non-cooperative situation resorting to argumentative hypocrisy. The paper will analyse some examples taken from the debate which led to the final version of the Italian Constitution.
\end{abstract}

Keywords: Argumentation theory, Political argumentation, Rhetoric, Constitutional law, Elster.

\begin{abstract}
Sumário. Jon Elster tem sugerido que até os falantes que não são movidos "por uma preocupação com o bem comum", e cujos interesses são puramente egoístas, podem ser obrigados ou induzidos a substituir a linguagem do egoísmo pela linguagem do argumento imparcial. Esta substituição seria o fruto da força civilizadora da hipocrisia. Esta hipocrisia argumentativa representa um conceitochave para interpretar um processo de negociação por meio de estratégias persuasivas, típico dos debates constituintes. Em particular, Elster defende que o requisito mais relevante de uma teoria da negociação deveria ser o facto de ter a capacidade de explicar o que acontece no caso de uma suspensão temporária da cooperação. A hipocrisia argumentativa pode permitir aos constituintes ultrapassar um impasse. Este artigo irá analisar alguns exemplos retirados dos debates que conduziram à versão definitiva da Constituição Italiana.
\end{abstract}

Palavras-chave: Teoria da argumentação, Argumentação política, Retórica, Direito constitucional, Elster. 


\section{o. Introduction}

In his Arguing and Bargaining, Jon Elster applies his argument from the civilizing force of hypocrisy to the analysis of two historical examples of constitution-making processes: the Philadelphia Convention of 1787 and the French revolutionary Assemblée Constituante (1789-1791) (Elster, 2000). As a source of impartiality, even if through a kind of deliberative heterogenesis of ends, the civilizing force of hypocrisy works as a powerful mechanism of mediation. In sum, even if used hypocritically, impartial arguments can lead to agreements based on general interest.

In this paper, I will briefly describe Elster's approach, underlining mainly its argumentative dimension. I will focus the analysis of the second paragraph on the double parallelism between, on the one hand, self-interested and impartial argumentation, and, on the other, "threat-based" and "warning-based" bargaining. In the third and the fourth paragraph I will present some examples, taken from the travaux preparatoires of the Italian Constituent Assembly (Assemblea Costituente, 1946/48), applying Elster's model to them. I will also address the main issue of the choice between publicity and secrecy of debates. In the fifth, I will try to show correspondences and differences between Elster's model and a debate in a real context, in particular from the point of view of the rhetorical dimension.

\section{Elster on the "civilizing force of hypocrisy"}

According to Jon Elster, the process of constitution-making can be described resorting to two types of - in his words - "speech acts": arguing and bargaining. The first type, based on "rational argumentation" is subject to "criteria of validity". The second, based on "threats' and promises", is subject to "criteria of credibility". Both types together form "the main vehicles by which the parties seek to reach agreement” (Elster, 2000, p. 372).

Considering the "type" of arguments used in constitutional debates, Elster makes a broad reference to two general categories: consequentialist or deontological arguments. In the first case, the framers "appeal to overall efficiency", while in the second "to individual rights". This second type, that of 
"right-based arguments", seems to be more "impartial", because "the rights are assigned to everybody" (Elster, 2000, p. 378).

Elster notices also that "consequentialist" arguments can imply a certain amount of impartiality. However, the use of deontological arguments seems to be much more effective: "framers can go to great lengths to make it appear that a measure whose real justification is obviously utilitarian can also be defended in terms of rights" (Elster, 2000, p. 391).

Taking into consideration the debates developed in two constituent processes - the Federal Convention in Philadelphia and the Assemblée Constituante in Paris from 1789 to 1791, Elster insists mainly on the role of rational argument in constituent decision-making, claiming that even the actors with "purely self-interested" concerns may be "forced or induced to substitute the language of impartial argument for the language of self-interest" - a kind of "substitution" that Elster attributes to what he calls "the civilizing force of hypocrisy" (Elster, 2000, p. 349).

This consideration leads Elster to conclude that the two original Habermasian commitments to truth and impartiality can coexist with a strategic use of impartiality and sincerity. Even if the framers are not genuinely committed to these values, "they may find it in their interest to appear to be so committed". In this case, "they engage (...) in strategic uses of purportedly non-strategic argument". In other words, self-interested actors may try to "ground their claims in principle" when "their self-interest tells them to appeal to an impartial equivalent of self-interest". This strategic function of "citing a general reason" has, according to Elster, an obviously persuasive goal, which is to increase the ability of the speaker to persuade others, and particularly, to persuade "the neutrals to agree" with him (Elster, 2000, pp. 405-409).

Finally, a kind of "substitution", analogous to that established in an argumentative context by the "civilizing force of hypocrisy", can also be found in a bargaining context. In the same way in which they may substitute an impartial argument for a direct statement of their interest, strategic actors "may also find it useful to substitute truth claims for credibility claims". In this case, "instead of making a threat whose efficacy depends on its perceived credibility, they may utter a warning that serves the same purpose and avoids the difficulties 
associated with threats". Indeed, according to Elster "warnings" are "factual equivalents" of a threat. Threats, "are statements about what the speaker will do", while warnings are statements "about what will (or may) happen, independently of any actions taken by the speaker." Thus, this substitution seems to be motivated by a strategic preference for (more persuasive) claims based on truth instead of (possibly less persuasive) claims based on credibility (Elster, 2000, p. 415). ${ }^{1}$ The "substitution" seems to be based on the rhetorical dimension of verisimilitude. A reference to (supposedly true) factual consequence is used in order to increase the persuasiveness of a mere appeal to (subjective) credibility.

Interestingly enough, this passage, which constitutes the argumentative side of the "civilizing force of hypocrisy" and which takes us from a sincere commitment to truth to a strategic sincerity, partly coincides with the Aristotelian definition of rhetorical discourse. In rhetoric, the possibility of the discourse being true is taken into consideration only as a means of persuasion: independently of the truthfulness of the premise or of the sincere commitment of the speaker to truth. What matters is the appearance of truth (Viano, 1955, p. 284): the persuasion of the audience about the truth. In other words, the civilizing force of hypocrisy is, in its essence, based on a rhetorical move.

If, as according to Elster, rational discussion is supposed to be based on "the power of the better argument", then constitutional bargaining "rests on resources that can be used to make threats (and promises) credible” (Elster, 2000, p. 392). Referring to these resources, from the viewpoint of the distinction between "the role of rational argument" and "threat-based bargaining in collective decision making", Elster explains that the paper focuses on "bargaining on the basis of extra-parliamentary resources, such as manpower and money” (Elster, 2000, p. 348). In other contexts he also makes reference to "extra-political" or "extraconstitutional" resources.

\section{The Italian Constituent Assembly}

\footnotetext{
${ }^{1}$ Whether these substitutions refer to a strategic use of argumentation or to a deceptive use of warnings is a question that - although relevant - is beyond the purposes of this paper. Both are examples, according to Elster, of "impartial equivalent of self-interest". As far as the "impartial equivalent" is concerned, the parallelism is relevant from my viewpoint. Although there can be clear differences between the two strategies.
} 
According to Elster, every constitution reflects not only the relative strength of the contending political forces within the Assembly, but also the political climate.

The Italian Constituent Assembly (Assemblea Costituente) was elected in 1946 (using proportional representation) with the first free and full elections in Italian history. The result of the election set up a balance between the main antifascist parties, the centrist Christian Democrats (DC) on one side (which won 35 percent of the vote) and the two leftist main parties on the other (the socialists of the PSI, with 21 percent of the vote, and the communists of the PCI, with 19 per cent). A third political position, the liberals, was also very influential even if numerically less significant (less than 10 per cent, adding together all the liberal parties).

As for the political climate, the work of the Assembly was threatened by external and internal circumstances. Internally, there were the obvious tensions inherent in the anti-fascist parties belonging to different political traditions: the Christian democrats, the Social-Communists, and the Liberals. Externally, there was the risk of a political crisis leading to civil war and, eventually, to foreign intervention. However, the main external influences affecting the work of the Assembly were the relations between political parties in view of the political elections of 1948. In particular, in May 1947 the Prime Minister (Presidente del Consiglio) Alcide De Gasperi, general secretary of the Christian Democratic Party, drove the communists out of the government with the aim of forming a new government, without the extreme left and obtaining the full support of the government of the United States. Italy could have followed the path of Greece in 1946-1947, with a bloody civil war and foreign intervention (Foot, 2003). However, De Gasperi and the general secretary of the Communist Party, Palmiro Togliatti, continued to collaborate even after May 1947, to draw up the Constitution.

The work of the Italian Constituent Assembly lasted 18 months, from 1946 to 1947 (with over 170 sittings).

As Elster noticed, a fundamental aspect of the institution of a constituent assembly concerns its internal procedural rules. The following issues can arise: a) it must decide whether to proceed in closed sessions or open the debates to the 
public; b) it may decide to create one or several subcommittees to prepare a draft of the constitution or to discuss special issues (Elster, 2000, p. 367).

Regarding this problem, a main concern expressed by the communist trade union leader Giuseppe Di Vittorio was that the secrecy of the sessions of the constitutional commission would have finally excluded "the people" from the drafting of the new Constitution (Pombeni, 2016, p. 112). ${ }^{2}$ As a matter of fact, the Italian solution was a mixed one: the sessions of the Assembly were public, but those of the commissions were closed. Indeed, in order to organize the work of the Assembly, the task of drafting constitutional provisions was delegated to a "Constitutional Commission" of 75 deputies (also known as "the Commission of the 75 ”), divided into three sub-commissions, each one chaired by a deputy of one of the three main parties3. The first sub-commission, tasked with drafting constitutional articles on the "Rights and Obligations of the Citizens", was chaired by the Christian Democrat deputy Umberto Tupini. The second and the third, on "Constitutional Organization of the State" and "Economic and Social Relationships", were chaired by the communist Umberto Terracini and the socialist Gustavo Ghidini, respectively. Finally, a Committee of 18 deputies (the "Committee of the 18") was given the task of writing an overall draft of the constitution, in accordance with the work of the three sub-commissions.

Working in subcommittees made it possible to have preliminary votes that did not commit the delegates to premature decisions. From this viewpoint, Elster quotes Jean-Josepph Mounier, leader of the moderates in the Assemblée Constituante: according to him, the committees favour "cool reason and experience," by detaching the members from everything that could stimulate their vanity and fear of disapproval. Particularly, in the case of closed sessions (such as in the Federal Convention) there is little risk of being prematurely locked into one opinion (Elster, 2000, p. 411). According to Elster, at the Federal

\footnotetext{
${ }^{2}$ According to Di Vittorio, the "most negative aspect" of the work method used in the Constituent Assembly were precisely the "small committees" which tended to exclude the "large public" from the debates and, above all, from the decision making process." It is necessary to note that the secretary of the Italian Communist Party took part in the debate in the commission and in the relative subcommissions, being one of protagonists of the constituent process - one of the few leaders who was directly involved in the debates and who was among the responsible for the organization of the Assembly. From this point of view, he acted in a pragmatic way, often driving his parliamentary group away from (potentially controversial) positions of principle or radical stances and towards both pragmatic positions and compromise solutions (Pombeni, 2016, p. 112).

3 "The next aspect of the constitution of the Constituent Assembly concerns its internal procedural rules. The following issues can arise ... It may decide to create one or several sub-committees to prepare a draft of the constitution or to discuss special issues" (Elster, 2000, p. 367).
} 
Convention the fear was that the pride and vanity of the delegates, as well as pressure from their constituencies, might have prevented them from backing down from an opinion once they had expressed it (Elster, 2000, p. 386). Another interesting effect of secrecy - Elster notes - is that of pushing the debates away from argument and towards bargaining (Elster, 2000, p. 386). Conversely, in public sessions (such as in the French Assemblée Constituante) there is stronger pressure against the expression of self-interest. A public setting encourages the use of pre-commitment through principle, with the larger audience serving as a resonance board for the claim and making it more difficult to back down (Elster, 2000, p. 410). According to Elster,

this difference between the two assemblies is reflected in the debates. Many of the debates at the Federal Convention were of high quality: remarkably free from cant and remarkably grounded in rational argument. By contrast, the discussions in the Assemblée Constituante were heavily tainted by rhetoric, demagoguery and overbidding. At the same time, the Convention was also a place where many hard bargains were driven, notably the deal between the slave holding and the commercial states (Elster, 2000, p. 411).

According to Elster, a positive consequence of secrecy also allows the possibility for a participant in the debate to change his or her mind. This can help reach a more cooperative and reasonable context, in which every participant is not strongly committed to coherence due to the external pressure of public opinion. As Elster noted, "the pursuit of understanding" can also be "constrained by a commitment to truthfulness or sincerity" and, in a habermasian fashion, "the outward form of truthfulness is consistency". However, while "a participant who is seen as choosing normative arguments à la carte ... will often be viewed as insincere", people "often modify their views by exposure to an argument." Elster notes that "framers in both assemblies believed that a major virtue of rational deliberation was that of allowing this to happen" (Elster, 2000, p. 377).4 We may also say that a (not necessarily genuine) change of mind can be instrumental in reaching an agreement on fundamental issues. During the debates of the Commission of the 75 a general problem concerning the framework of the Constitution was presented with the so called Bozzi Motion [Ordine del giorno Bozzi], subscribed by, among the others, Giovanni Lombardi (PSI), Mario Cevolotto (Liberal), Amintore Fanfani (DC), Tomaso Perassi (Republican), Piero

\footnotetext{
4 'Nevertheless, genuine changes of mind can often be distinguished from opportunism. Explicit disavowal of one's earlier views, and attempts to remedy earlier decisions, would be one criterion. Claiming to be persuaded by normative arguments that are counter to one's self-interest would be another. Although neither criterion is infallible, both can be helpful" (Elster, p. 2000, p. 377).
} 
Calamandrei (Liberal-socialist) and Francesco M. Dominedò (DC). 5 This motion committed the framers to write a Constitution as far as possible simple and clear, so that it would be comprehensible "for the entire people", and limited to "essential norms" and "concrete dispositions", and to abstain from stating "general programs" and political "desires". Key leaders both of the Christian democrats (Giuseppe Dossetti and Costantino Mortati) and of the Communist Party (Togliatti) criticized the motion as "equivocal", defending the programmatic character of the Constitution (Togliatti) and the freedom of the framers (Mortati). At this point, Fanfani (one of the main subscribers) withdrew from his initial position and partially agreed with Togliatti on the programmatic nature of a Constitution: a program which was not - in his words - a mere "hope", but a clear "will". Interestingly enough, this change of mind led to a major compromise on the motion, based on an ambiguous reformulation. The Motion was ultimately approved, but a vote declaration of Tupini opened the door to a more flexible interpretation of the text (Pombeni, 2016, pp. 206-208). Tupini's vote declaration can also be considered a kind of hypocritical commitment and an "incompletely theorized agreement" (Sunstein, 2007), something that originates from conflicting opinions, but which nevertheless concludes with participants agreeing on a single outcome, but for different reasons (Mansbridge et al., 2010). We will come back to this issue infra. What is relevant to show here is that Fanfani's (at least) partial change of mind would have been probably if not impossible, at least very difficult in a public plenary assembly.

Generally speaking, it is possible to say that, in the Italian case, the joint process of the (closed) committees and of the (public) assembly favoured the drafting of a Constitution largely based on a set of political compromises. The main example of such a compromise is Article 7, which established a privileged status for the Church in the new Republic, including (with the approval of the communists) the Concordat between the Church and the fascist State, included in the "Lateran Pacts" (Patti Lateranensi) of 1929. Other compromises ended with the independence of the Constitutional Court - a defeat for the Communists - or the Christian Democratic retreat from a corporativist and regionalist model, which can be viewed as a victory of the liberals. One of the main Christian

${ }^{5}$ The Motion had been presented by the liberal MP Aldo Bozzi on October 25, 1946. 
Democratic defeats came when the final constitutional text no longer proclaimed the indissolubility of marriage (Einaudi, 1948, pp. 662-663). Thus, it may be interesting to take into consideration some examples of such "compromises" and compare them with Elster's framework.

\section{The debate in the sub-commissions}

Analysing the debate in the commissions, we find many characteristics included in Elster's model. First of all, we find a bargain conducted resorting to internal and external resources. Among the internal resources, we may find the use of logrolling or vote-trading, which is the practice of exchanging favours by reciprocal voting for each other's proposed legislation.

During the debate concerning the inclusion in the Constitution of the indissolubility of matrimony (strongly endorsed by the Christian democrats and equally strongly opposed by the left wing parties and some of the liberals) a first compromise was ultimately found, including in the provisional draft a definition of family as a "natural society", and dropping any reference to the "indissolubility" of marriage. Also in this case, the agreement was reached by Togliatti (PCI) and Aldo Moro (DC) on the basis of a (strategically) ambiguous reformulation of the text. The expression "natural society", indeed, allows for multiple interpretations, and the agreement was clearly on the level of the wording, and not on that of the (different) possible interpretations.

When the text was submitted in the Commission of 75 for approval, Togliatti, following the previous agreement, gave instructions to the communist deputies about how to vote. According to this logrolling strategy, the Communists allocated their votes in a way that ultimately permitted the approval of the expression "natural society".

The debate on the issue of the definition of marriage was thus made difficult by the strong resistance of the Catholic MPs (Giorgio La Pira and Dossetti, particularly) who sensed that this issue was absolutely crucial. During the debate, the direct threat of withdrawing from the commission was substituted by the warning that it could cause a secession in the commission. The Socialist Lelio Basso, in particular, warned the Christian Democrat MPs against causing a secession with what he interpreted as stubborn behaviour. A kind of substitution 
of a threat with a warning, based, in this case, on "extra-parliamentary resources"6.

However, these strategies where ultimately ineffective, and the final draft included both the definition of family as "natural society" and the indissolubility of marriage. The issue was finally solved by resorting to a strategic use of the rules of the Assembly. In the General Assembly, the last passage before the final approval of the article was the vote of the amendment presented by the socialist MP Umberto Grilli, who proposed again to eliminate the term "indissolubility". Before voting, twenty deputies called for a secret ballot. This was quite an unusual demand, based however on the rules of the pre-fascist Chamber of Deputies, which the Constituent Assembly decided to adopt. Thanks to this strategic use of a pre-existing institutional framework, which reduced the influence of the parties (and also of public opinion) over the deputies, the indissolubility of marriage was not included in the Constitution.

Considering the argument used, every party tried to use "impartial" arguments, even if of a different kind. We know that every party had strongly "egoistic" reasons, mainly related to the imminent electoral campaign. However, they substituted the language of impartial argument for the language of selfinterest.

The debate on article 29 and the possibility of introducing the indissolubility of marriage also provides a good example from this point of view. Even if the Christian democrats MPs were convinced that this position was not simply related to Catholic doctrine, but was ultimately based on the very "nature" of marriage, they also felt that it should have been justified on the basis of "universalizable" arguments. For this reason, they made it clear that they were referring to marriage not as a sacrament (which was already recognized by the church as indissoluble), but as a legal institution. Thus, they presented philosophical, consequentialist (based on "the unity of family"), and even "scientific" reasons for defending its indissolubility. La Pira used a kind of "tu quoque" argument, suggesting that the communist's opposition to the

\footnotetext{
${ }^{6}$ Making reference to "extra-constitutional bargaining", Elster notes that "one party may act on the assumption that the other will be unwilling to be seen as responsible for breaking off negotiations" and he gives a similar example: "during the debates over the Spanish constitution in 1978, the Union of the Democratic Center was accused 'of breaking a painstakingly negotiated set of compromises', leading to the withdrawal of the Socialist member on the subcommittee" (Elster, 2000, p. 394, and n. 223).
} 
indissolubility of marriage was ultimately contradictory, considering that divorce was practically banned in the Soviet Union (Damele, 2016).

This type of argument was somewhat common in the Assembly at the time. It was also used in its version of a kind of "impartial" use of the argument from authority, based on the appeal to someone who is mainly considered as a political authority by the adversary. As Mario Einaudi noticed, "the Communists called in the authority of George Washington and relied on Benjamin Franklin to weaken the argument for an upper chamber, while the Christian Democrats quoted at length the authority of Stalin to support the thesis that the two chambers had to be of equal power" (Einaudi, 1948, p. 662). This kind of use of the argument from authority can also be considered hypocritical, since it makes reference to somebody who, under normal circumstances, would not be considered a political or moral reference point by the speaker. In this case, the hypocritical nature of the argumentation is quite explicit. On the other hand, the appeal to someone who is regarded as a political authority by the adversary, increases the appearance of impartiality, for persuasive purposes. From Elster's viewpoint, the speaker is not necessarily impartial: he exploits impartiality for self-interested purposes. Nevertheless, Elster thinks that even this self-interested use of impartiality can have a "civilizing" force, due to the fact that, in a sense, it speaks (even if for egoistic purposes) the language of universalizable arguments.

Other examples show a strategic use of a hypocritical discourse, with the purpose of persuading different audiences. It can be interesting, from this viewpoint, to consider the different strategies used by Christian democrats MPs in order to justify their work in the Constituent Assembly towards their electorate and the Catholic hierarchy, and compare them with the persuasive techniques used by the same politicians within the commissions, in order to reach agreement.

There was strong pressure, coming from the Vatican and the Catholic hierarchies, particularly on issues such as family, education and the role of the Catholic Church. In many cases, Catholic deputies tried to defend Catholic positions resorting to impartial arguments. Then, when this strategy was effective, they presented it as a victory for a Catholic point of view. This strategy was especially common during debates on social issues, when Christian Democrat 
deputies invited Communist and Socialist deputies to leave aside terminological questions, and consider the essence of the problem, in order to reach a solution. However, when they had to defend their decision on articles published in the official press of the Catholic Church or of the Christian Democratic party, they presented that same solutions as purely based on the social doctrine of the Catholic church.

Discussing the approval of the whole Constitution, in the Christian Democrat newspaper "Il Popolo", La Pira (one of the leaders of the "left wing" of the Christian democrat party) stated that "it is possible to say, without errors, that the organic conception, typical of the Christian sociology ... it is on the very base of this Constitution."7 A kind of argument used with the aim of persuading the Catholic hierarchy about the acceptability (from their own viewpoint) of the Constitution. However, during the meetings of the Commission of the 75, La Pira, together with other Christian Democrat leading figures such as Dossetti and Moro, resorted to a different strategy, based on a universalization of the argument, with the aim of showing that, under the surface of different ideological and religious viewpoints, there was a deep common ground. Reference was made, for example, to a general evolution of the contemporary thinking, which resulted in a wide convergence between different ideological positions, on fundamental issues, such as, for example, labor law. In other words, on the one hand, the strategy was that of persuading the electorate and Catholic hierarchies (suspicious of the socialist and communist influence in the Constituent Assembly) that they were succeeding in drafting a constitution which was "Christian" in its fundamental inspiration. On the other hand, it was that of persuading political adversaries that, under different expressions, they all shared the same fundamental ideas. The objective of this double strategy was, fundamentally, a legitimation of the compromise, now represented as a strategic move necessary to obtain political success on issues that were instrumental from the point of view of Catholic social teaching (Pombeni, 2016, p. 117). Such a strategy can be considered, from Elster's point of view, a good example of the civilizing force of hypocrisy: the necessity to reach an agreement force to "universalize" their own point of view (that is, to give an "impartial" version of a

${ }^{7}$ Session of December 23, 1947 
"partial" or "egoistic" point of view), only to come back to the original "partial" argument when the strategy is that of persuading the electorate or also, in the case of Christian Democrat MPs, the Catholic hierarchy. Clearly, in this second case, a kind of strategy like that used by the Commission, based on the idea of a deep common ground between different ideological points of view, would have been less effective, due to the position of the Catholic church (quite suspicious regarding "compromises" with the social-communists) or the polarization of the electorate.

\section{Conclusions}

The choice made by the constituent fathers to organize the Constituent Assembly's work into two sessions - closed drafting commissions and a public plenary assembly - favored compromises, allowing, according to Elster's scheme, shifts from arguing to bargaining and (in relevant cases) a change of mind or withdrawal. Many of the strategies described by Elster as ways to (tacitly or expressly) reach agreement through negotiation can be found, such as logrolling or the strategic use of procedural rules in general. From a discursive point of view, examples of substitution both of impartial arguments for the language of selfinterest and warnings for direct threats can be found. Particularly relevant, from a rhetorical point of view, is the strategy used by the Christian Democrat MPs of using "partial" arguments while addressing their electorate or the Catholic hierarchies and "impartial" arguments in order to persuade their political adversaries - a clear example of adaptation of the persuasive strategy to the (particular) audience.

Many of these strategies can represent, from Elster's point of view, examples of the "civilizing force of hypocrisy", in as much as they imply a kind of universalization (mainly in the case of the substitution of the "impartial" for "partial" arguments) and the substitution of a subjective threat with an objective warning. Both strategies are, in the examples taken into consideration, instrumental to negotiation.

It has become common to refer to the Italian Constitution as an example of "high-profile agreement", different from the low profile compromises of the "politique politicienne", which resulted in a process of "higher law making" (in Bruce Ackermann's words). This is certainly true, due in part to the general 
context and to the sense of responsibility of the "constituent fathers" (or at least of their leaders). First of all, the constituent fathers were well-aware of being in a kind of "veil of ignorance" situation. A crucial problem was that of the future electoral weight of each political party, something that suggested a solution based on a strong system of checks and balances, with the purpose of preventing the exploitation of a strong position, transforming an electoral advantage into a powerful domination of the whole system. Secondly, in a (highly) pluralistic political landscape, compromises are not only inevitable, but the desired result of the political (in this case constituent) process. Arguing, bargaining through threats and promises, are fundamental strategies instrumental to reaching such an agreement. However, it is also important to look, realistically, at the outcomes of such a strategy. We made a reference, supra, to Sunstein's concept of "incompletely theorized agreement. This peculiar method of statute-making, aimed at reducing the potential for conflict, is based, according to Sunstein, on an agreement on abstractions, to which an agreement on the particular meaning of those abstractions does not correspond.

Thus, ambiguity is used strategically to foster agreement on abstractions without limiting specific interpretations (Eisenberg, 1984). This technique, which according to Eisenberg corresponds to a "more rhetorical view of communicator as strategist", is particularly used by collective agents like legislatures. In this context, people "confront multiple situational requirements, develop multiple and often conflicting goals, and respond with communicative strategies which do not always minimize ambiguity, but may nonetheless be effective" (Eisenberg, 1984, pp. 227-238)

As Hans Kelsen has noted, this exploitation of ambiguity can be part of a legislative technique which tends "to leave a large latitude to the authority charged with its application or interpretation" by "intentionally formulating the rules in a vague, indefinite, equivocal way" (Kelsen, 1939, p.11, 17). This choice of vague or indefinite terms seems to make the decision "easier when the interests are strongly opposed". However, "the real concordance of wills" can be "only an illusion", which is "very quickly dissipated when it becomes necessary to apply the norm formulated in indefinite terms". Then, "it is realized that the ... parties 
have aimed at very different ends under the cover of the words with which the norm to be applied is expressed".

\section{References}

Ackerman, B. (1991). We the People. Vol. 1: Foundations. Harvard: Harvard University Press.

Damele, G. (2016). The Bearable Ambiguity of the Constitutional Text. Arguing, Bargaining and Persuading in the Italian Constituent Assembly. In D. Mohammed, \& M. Lewiński (Eds.), Argumentation and Reasoned Action (Vol. 1) (pp. 75-90). Milton Keynes: $\quad$ College Publications.

Einaudi, M. (1948). The Constitution of the Italian Republic. The American Political Science $\quad$ Review, XLII(4): 661-676.

Eisenberg, E.M. (1984). Ambiguity as Strategy in Organizational Communication, Communication Monographs, 51: 227-242.

Elster, J. (2000). Arguing and Bargaining in Two Constituent Assemblies, University of $\quad$ Pennsylvania Journal of Constitutional Law, 2: 345-419.

Kelsen, H. (1939). Legal Technique in International Law. Geneva: Geneva Research Centre.

Mansbridge, J. et al., (2010). The Place of Self-Interest and the Role of Power in Deliberative Democracy, Journal of political philosophy, 18(1): 64100.

Sunstein, C.R. (2007). Incompletely Theorized Agreements, Constitutional Law. Public Law and Legal Theory Working Paper, 147 (University of Chicago - Law School).

Pombeni, P. (2016). La questione costituzionale in Italia. Bologna: il Mulino.

Viano, C.A. (1955). La logica di Aristotele. Torino: Taylor. 